\title{
Development of the Life Insurance Market in Albania
}

\author{
Assoc. Prof.Dr Filloreta Madani \\ University of Vlora "Ismail Qemali", Faculty of Economy
}

Assoc. Prof.Dr Evelina Bazini

University of Vlora "Ismail Qemali", Faculty of Economy

\begin{abstract}
Life insurances occupy a small part in the insurance market in developing countries. The new age of the insurance industry and the level of the economic development in Albania make the life insurance market even more fragile. Factors affecting the development of this market are influenced by the economic growth and by other factors such as inflation, education of population, population growth, government policies, private investment, etc. In this article we will analyze using statistical methods the degree of the impact of the above factors in the life insurance market and we will also analyze through penetration coefficients the impact of the life insurance industry in Albania's economic development.
\end{abstract}

Keywords: Life insurance, age, income per capita, level of education, Non-life insurance

\section{Introduction}

\section{The methodology of the study:}

The purpose of this study is to make a detailed account of the life insurance market in Albania based on statistical data analysis, the study of the theories on life insurance development in developing countries, their characteristics and the alignment with the reality of the security life in Albania. Another aim of this study is the collection of secondary data from national and international sources, which will serve us for an empirical analysis. The statistical methods of data help to determine the degree of processing of factors that influence the level of demand for life insurance in Albania.

Hypothesis: The claim for insurance is influenced by the economic growth and is influenced by factors such as inflation, education, population growth, government policies, private investment, etc.

\section{Introduction}

Life insurance as an important part of the insurance industry plays an important role in the development of the financial system. Theoretical and empirical conclusions often rank developed countries at the top of the list of countries that have a developed sector of life insurance. It happens that these findings may be contradictory because less developed countries can have a development on the insurance sector larger compared to that in developed countries. Thus, according to Thorsten Beck and lan Webb, South Africa has had a rate of penetration in life insurance of $7.4 \%$, compared with developed countries. The rate of penetration in life insurance is the norm in percentage of the volume of insurance premiums to the Gross Domestic Product life. In developed countries, premiums from life insurance are higher than premiums from life insurance and vice versa for developing countries. In EU countries, except Austria, where the non-life insurance prevail over life insurance, is noticed the same trend of prevalence of life insurance in most developed countries. The life insurance market dominates with $60 \%$ against non-life insurance market which owns only $40 \%$ of the insurance market in Europe. However, here we distinguish a significant difference, the dominance of non-life insurance sector, especially in Eastern European countries. (Romania, Bulgaria, Estonia, Slovenia). 
Table 1 The structure of the insurance market

\begin{tabular}{|c|c|c|c|c|c|c|c|c|c|c|c|c|c|c|c|c|}
\hline & \multicolumn{2}{|c|}{2002} & \multicolumn{2}{|c|}{2005} & \multicolumn{2}{|c|}{2008} & \multicolumn{2}{|c|}{2009} & \multicolumn{2}{|l|}{2010} & \multicolumn{2}{|c|}{2011} & \multicolumn{2}{|c|}{2012} & \multicolumn{2}{|c|}{2013} \\
\hline & Life & $\begin{array}{l}\text { Non } \\
\text {-Life }\end{array}$ & Life & $\begin{array}{l}\text { Non } \\
\text {-Life }\end{array}$ & Life & $\begin{array}{l}\text { Non } \\
\text {-Life }\end{array}$ & Life & $\begin{array}{l}\text { Non } \\
\text {-Life }\end{array}$ & Life & $\begin{array}{l}\text { Non } \\
\text {-Life }\end{array}$ & $\begin{array}{l}\text { Lif } \\
\mathrm{e}\end{array}$ & $\begin{array}{l}\text { No } \\
n \text { - } \\
\text { Lif } \\
\text { e }\end{array}$ & $\begin{array}{l}\text { Lif } \\
\mathrm{e}\end{array}$ & $\begin{array}{l}\text { No } \\
n- \\
\text { Lif } \\
\text { e }\end{array}$ & Life & $\begin{array}{l}\text { Non } \\
\text {-Life }\end{array}$ \\
\hline EU & $\begin{array}{l}62 \\
\%\end{array}$ & $38 \%$ & $\begin{array}{l}63 \\
\%\end{array}$ & $37 \%$ & $\begin{array}{l}61 \\
\%\end{array}$ & $39 \%$ & $\begin{array}{l}61 \\
\%\end{array}$ & $39 \%$ & $61 \%$ & $39 \%$ & $\begin{array}{l}59 \\
\%\end{array}$ & $\begin{array}{l}41 \\
\%\end{array}$ & $\begin{array}{l}59 \\
\%\end{array}$ & $\begin{array}{l}41 \\
\%\end{array}$ & $60 \%$ & $40 \%$ \\
\hline $\begin{array}{l}\text { Alba } \\
\text { nia }\end{array}$ & $\begin{array}{l}7.5 \\
0 \%\end{array}$ & $\begin{array}{l}92.5 \\
0 \%\end{array}$ & $\begin{array}{l}6.0 \\
0 \%\end{array}$ & $\begin{array}{l}94.0 \\
0 \%\end{array}$ & $\begin{array}{l}7.3 \\
0 \%\end{array}$ & $\begin{array}{l}92.7 \\
0 \%\end{array}$ & $\begin{array}{l}9.2 \\
0 \%\end{array}$ & $\begin{array}{l}90.8 \\
0 \%\end{array}$ & $\begin{array}{l}10.5 \\
0 \%\end{array}$ & $\begin{array}{l}89.5 \\
0 \%\end{array}$ & $\begin{array}{l}13 \\
\%\end{array}$ & $\begin{array}{l}87 \\
\%\end{array}$ & $\begin{array}{l}10 \\
\%\end{array}$ & $\begin{array}{l}90 \\
\%\end{array}$ & $\begin{array}{l}11.5 \\
0 \%\end{array}$ & $\begin{array}{l}88.5 \\
0 \%\end{array}$ \\
\hline
\end{tabular}

Source: Eurostat, Annual Reports 2002-2013 AFSA

\section{Literature review}

Savings in developing countries are very low, a result observed in both indicators, in absolute terms and in relation with the economic growth rate of developing countries.

This point of view, however, ignores the fact that the savings rate is linked to a number of factors that influence it, regardless of the system.

There have been numerous empirical studies to determine the factors affecting supply and demand in life insurance. Some of our research is mentioned below:

Following the theory of Yaari (1964-1965) and Hakansson (1969) a function of demand for life insurance is derived from the maximization of customer service function.

The function of customer uses should depend on wealth, current income, on a vector of interest rates, a price vector, including premium life insurance, and the functions of subjective customer deductions for services for consumption and wealth, which are influenced by the level of financial market development. (See also Outureville, 1985).

Headen and Lee (1974) studied the behavior of short-term financial markets and consumer expectations demand for ordinary life insurance. They concluded that the demand for life insurance is inelastic and positively influenced by changes in customers' opinions. Interest rates play a role in the short-term as well as in the long-term financial markets.

In studies of Truett et al. (1990) it was discussed a pattern of growth of life insurance consumption in Mexico and the United States in a comparative context, during the period 1964 to 1984. They assumed that a certain level of demand depends on the price of insurance, the level of the individual's income, the possibility of substitution, age and education.

The basic motives for savings in developing countries should be the same as those of the industrialized countries. However environments in which decisions are made for savings are completely different.

At the same time, because the income earned as a function of age does not follow the same pattern, it is only an assumption to say that a change in the rate of population growth does not affect the distribution of generation income. In the context of savings for the least developed countries, the hypothesis of the life cycle may be less powerful to explain the total savings rate. Capital markets in many less developed countries are often poorly organized. The time of consumption because of necessity may be closely related to current income more than is allowed in the problem of individual maximization. Some of these effects can be compensated by intra familiar transfers within an extended family. (Kotlikoff and Summers, 1981).

A second concern is the growth rate of the population and at the same time the existence of an asymmetrical distribution of personal income. A rapid increase in population brings a large number of young people who tend to consume more than they have. In this context, Hammer indicates that an increase in the rate of population growth caused by an increase in the total fertility rate reduces savings.

The belief for a long time, that an equal distribution of income encourages savings of groups with low incomes, poses a difficult problem for many developing countries. Moreover, a relatively high proportion of families in developing countries 
derive its income from agriculture, and earnings are subject to significant fluctuations due to variations in the world price of agricultural commodities and climatic conditions.

The structural characteristics of financial institutional markets play a major role in determining the efficient distribution of supply and demand for financial services. Changes arise when a government decides to tax and undertake measurements. A variety of factors, especially the economies of developing countries can affect the propagation of price change.

"Financial repression" typically describes a set of policies that aim to use the financial system to channel resources into specific sectors of the economy. (Gang and Feldman, 1990). A government can force sales of government debt for the insurance industry or the use of controls on interest rates. Artificially, low real interest rates reduce the total income of life insurance companies, as well as the supply of capital, and therefore the insurance of companies' ability to respond to potential requests. There are also many other studies related to specific countries or a group of countries that treat factors influencing the life insurance and insurance in general.

We think there are some macroeconomic variables such as income, interest rates and the accumulation of savings in the form of property; along with a group of social or demographic variables that have a significant impact on the decisions of individuals in Albania to choose whether or not to seek life insurance. The consumption for life insurance increases with the possibility of a death risk of the person who holds the family, the current level of domestic consumption, and the degree of risk rejection.

\section{Chapter 1: Measuring the economic importance of the life insurance market in the country's development}

The security role in the development process is difficult to be accepted, but there is evidence showing that policy support for life insurance can have a significant impact on the level of many developing countries savings. (UNCTAD 1982). However, the market for life insurance remains low in developing countries.

The economic importance of life insurance is measured by premiums compared to GDP rates. The life insurance sector has little significance, since in most developing countries the life insurance may be considered irrelevant or inappropriate for ideological, cultural or religious reasons or economic security covered by the family itself. Availability of insurance is thought to be related to GDP. Links between written premiums of life insurance per capita and GDP per capita are assumed to be non-linear. Exchange rates play an important role and the possibility of imperfect statistics does the same.

Measures of insurance companies which contribute to the financing of the national economy are calculated by comparing the incorporation of technical reserves and provisions (assets) of insurance companies in the financial requirements of the national economy.

Table 1.1. Provision of life insurance companies in Albania

(In 000000 Lek)

\begin{tabular}{|l|l|l|l|l|l|l|l|l|l|l|l|l|}
\hline Years & 2003 & $\begin{array}{l}200 \\
4\end{array}$ & 2005 & $\begin{array}{l}200 \\
6\end{array}$ & $\begin{array}{l}200 \\
7\end{array}$ & 2008 & $\begin{array}{l}200 \\
9\end{array}$ & 2010 & 2011 & 2012 & 2013 & 2014 \\
\hline Total Assets & 48 & 88 & 131 & 218 & 227 & 233 & 444 & 2,473 & $\begin{array}{l}2,88 \\
4\end{array}$ & $\begin{array}{l}3,20 \\
7\end{array}$ & 3,788 & 4,008 \\
\hline Total Investments & 625 & 706 & 898 & 793 & $\begin{array}{l}103 \\
7\end{array}$ & 1389 & $\begin{array}{l}173 \\
8\end{array}$ & 1832 & 1992 & 1996 & 2812 & 3050 \\
\hline $\begin{array}{l}\text { Gross technical } \\
\text { provisions }\end{array}$ & 508 & 628 & 868 & 868 & $\begin{array}{l}100 \\
1\end{array}$ & 1248 & $\begin{array}{l}126 \\
4\end{array}$ & 644 & 853 & 942 & 1,175 & 1,522 \\
\hline
\end{tabular}

Source: AFSA, Albanian Life Insurance Companies

Often such data are lacking or are not accurate and can be fall into the trap of evidence data, the most acute problem for developing countries and less evident in developed countries. It is very important where Life insurance companies in Albania invest and how they affect the development of the financial system. From observations of balances of life insurance companies in Albania, it is noted that $67-70 \%$ of their investments are in bank deposits and the rest in securities of government securities. If we refer to Eurostat data, portfolios of investments of European countries are very diverse. On average, $50 \%$ of its portfolio is destined to "debt securities with fixed income", $23 \%$ of the portfolio in stocks, $7 \%$ in participation, $3 \%$ in real estate, only $1.3 \%$ in treasury bills and the portion that remains are other types of investments not 
mentioned above. It is natural that the impact of the life insurance companies on these countries is very important in the financial system and then to the whole economy.

In our study of life insurance contribution in the economy we will deal with two other indicators, the insurance density of life which is the premium per capita and the rate of penetration that is the sum of premiums as a percentage of GDP.

Table 1.2 Coefficients of penetration Total premiums / GDP

(EU, Albania, $2004-2013$, in \%)

\begin{tabular}{|c|c|c|c|c|c|c|c|c|c|c|}
\hline & 2004 & 2005 & 2006 & 2007 & 2008 & 2009 & 2010 & 2011 & 2012 & 2013 \\
\hline Austria & 6.0 & 6.2 & 6.0 & 5.8 & 5.7 & 5.9 & 5.9 & 5.5 & 5.3 & 5.3 \\
\hline Belgium & 9.8 & 11.1 & 9.2 & 9.3 & 8.5 & 8.3 & 8.3 & 7.9 & 8.6 & 7.3 \\
\hline Bulgaria & 1.9 & 2.1 & 2.4 & 2.5 & 2.6 & 2.4 & 2.3 & 2.1 & 2.0 & 2.2 \\
\hline Switzerland & 10.9 & 10.6 & 9.7 & 9.2 & 9.4 & 9.7 & 9.6 & 9.5 & 9.6 & 9.8 \\
\hline Cyprus & 7.5 & 7.6 & 7.6 & 4.5 & 4.5 & 4.8 & 4.9 & 4.8 & 4.7 & 4.7 \\
\hline Czech Republic & 3.6 & 3.5 & 3.5 & 3.4 & 3.4 & 3.6 & 3.9 & 3.8 & 3.7 & 3.7 \\
\hline Germany & 6.9 & 7.1 & 7.0 & 6.7 & 6.7 & 7.2 & 7.2 & 6.8 & 6.8 & 6.8 \\
\hline Denmark & 7.9 & 7.9 & 8.3 & 8.5 & 8.7 & 9.1 & 8.9 & 9.3 & 8.6 & 9.5 \\
\hline Estonia & 2.1 & 2.3 & 2.2 & 2.3 & 2.0 & 2.2 & 2.0 & 1.7 & 1.7 & 1.7 \\
\hline Spain & 5.4 & 5.4 & 5.4 & 5.2 & 5.4 & 5.8 & 5.4 & 5.7 & 5.5 & 5.4 \\
\hline Finland & 8.7 & 9.1 & 9.0 & 8.4 & 8.5 & 9.4 & 10.4 & 9.6 & 10.3 & 11.3 \\
\hline France & 9.6 & 10.2 & 11.0 & 10.4 & 9.5 & 10.6 & 10.7 & 9.5 & 8.9 & 9.1 \\
\hline Greece & 2.0 & 2.0 & 2.1 & 2.2 & 2.2 & 2.3 & 2.4 & 2.3 & 2.2 & 2.1 \\
\hline Croatia & 2.7 & 2.8 & 2.8 & 2.8 & 2.8 & 2.9 & 2.9 & 2.8 & 2.8 & 2.8 \\
\hline Hungary & 2.9 & 3.1 & 3.5 & 3.7 & 3.4 & 3.2 & 3.2 & 3.0 & 2.7 & 2.8 \\
\hline Ireland & 8.0 & 8.3 & 9.1 & 9.6 & 7.5 & 7.7 & 8.0 & 7.0 & 6.6 & 6.9 \\
\hline Iceland & 2.6 & 2.6 & 2.6 & 2.7 & 2.7 & 2.7 & 2.8 & 2.7 & 2.8 & 2.7 \\
\hline Italy & 7.2 & 7.6 & 7.1 & 6.4 & 5.8 & 7.8 & 8.1 & 7.0 & 6.7 & 7.6 \\
\hline Liktenshtein & 53.5 & 92.2 & 135.2 & 125.0 & 108.7 & 183.2 & 177.8 & 93.1 & 64.7 & 66.7 \\
\hline Luxembourg & 3.0 & 3.3 & 3.0 & 2.9 & 4.6 & 4.6 & 5.3 & 3.9 & 4.3 & 4.6 \\
\hline Lithuania & 1.2 & 1.2 & 1.3 & 1.5 & 1.5 & 1.2 & 1.0 & 0.7 & 0.9 & 0.9 \\
\hline malta & 11.9 & 12.2 & 12.8 & 6.3 & 4.6 & 4.8 & 5.0 & 4.6 & 3.9 & 4.1 \\
\hline Hollande & 9.9 & 9.5 & 13.6 & 13.1 & 13.2 & 13.6 & 13.3 & 13.1 & 12.5 & 12.5 \\
\hline Norway & 5.0 & 4.9 & 4.4 & 4.5 & 4.1 & 4.3 & 4.3 & 4.3 & 4.5 & 4.4 \\
\hline Poland & 3.0 & 3.2 & 3.5 & 3.7 & 4.6 & 3.8 & 3.8 & 3.7 & 3.9 & 3.5 \\
\hline Portugal & 7.0 & 8.7 & 8.2 & 8.1 & 8.9 & 8.6 & 9.5 & 6.8 & 6.6 & 7.9 \\
\hline Romania & 1.0 & 1.1 & 1.3 & 1.6 & 1.7 & 1.5 & 1.6 & 1.4 & 1.2 & 1.3 \\
\hline Sweden & 6.5 & 7.5 & 7.3 & 7.4 & 7.5 & 8.0 & 8.1 & 7.7 & 6.4 & 6.9 \\
\hline Slovenia & 5.4 & 5.4 & 5.6 & 5.5 & 5.4 & 5.8 & 5.9 & 5.6 & 5.7 & 5.5 \\
\hline Slovakia & 3.5 & 3.4 & 3.2 & 3.1 & 3.2 & 3.2 & 3.0 & 2.9 & 2.9 & 3.0 \\
\hline Turkey & 0.7 & 0.7 & 0.8 & 0.8 & 0.8 & 0.9 & 0.9 & 1.0 & 1.1 & 1.3 \\
\hline United Kingdom & 13.8 & 14.3 & 14.9 & 17.6 & 13.5 & 12.9 & 11.9 & 12.1 & 13.0 & 12.2 \\
\hline Insurance in Europe & 8.0 & 8.3 & 8.5 & 8.5 & 7.7 & 8.3 & 8.1 & 7.7 & 7.6 & 7.7 \\
\hline Insurance in Albania & 0.5 & 0,48 & 0,51 & 0,61 & 0,65 & 0,69 & 0,67 & 0,62 & 0,66 & 0,63 \\
\hline
\end{tabular}

Source: Eurostat, AFSA

Compared in time, the contribution of the insurance sector in our country has had no growth significance in absolute terms, although in relative terms it is increased by $26 \%$. This shows that increasing capacities exist but the real effect is very small, perhaps negligible. 
Table 1.3 Coefficients of penetration Life Prime / GDP, (EU, Albania , $2004-2013$, in \%)

\begin{tabular}{|l|l|l|l|l|l|l|l|l|l|l|}
\hline & 2004 & 2005 & 2006 & 2007 & 2008 & 2009 & 2010 & 2011 & 2012 & 2013 \\
\hline $\begin{array}{l}\text { Penetration } \\
\text { Coefficient of Life } \\
\text { Insurance in EU }\end{array}$ & 5.0 & 5.2 & 5.3 & 5.3 & 4.9 & 5.0 & 5.0 & 4.5 & 4.5 & 6.0 \\
\hline $\begin{array}{l}\text { Penetration } \\
\text { Coefficient of Life } \\
\text { Insurance in Albania }\end{array}$ & 0.020 & 0.030 & 0.030 & 0.040 & 0.050 & 0.060 & 0.070 & 0.050 & 0.066 & 0.072 \\
\hline
\end{tabular}

Source: Eurostat, AFSA

Another important indicator of the contribution is the life insurance density per capita premium. This indicator is an accurate gauge and very important to understand the influence of life insurance in a country's economy and also to show how much Albanians spend for life insurance.

Table 1.4 Life Premium / per capita ( in euro)

\begin{tabular}{|l|l|l|l|l|l|l|l|}
\hline Years & 2005 & 2008 & 2009 & 2010 & 2011 & 2012 & 2013 \\
\hline EU (in euro) & 1067.5 & 1145.5 & 1137.8 & 1159.4 & 1087.4 & 1088.4 & 1129.6 \\
\hline Albania (in euro) & 2 & 2.2 & 2.1 & 2.2 & 2.3 & 2.3 & 2.5 \\
\hline
\end{tabular}

Source: Eurostat, AFSA Annual Reoprt

Albania has the smallest insurance market across Europe. The premium per capita in 2013 was only 21 euros for the Albanians, while a year ago it was 23 euros. The average premium per capita in the EU is 1860 euros for insurance in total or 85 times higher than the premium per capita in Albania. This figure is also lower than in Kosovo, where per capita premiums are 38 Euro. Macedonia has 54 euros per capita premiums while Croatia 280 euros. If we compare per capita premiums of life insurance the situation is more dramatic. These premiums do not exceed 2.5 euro / capita, while European countries have a premium of 1050 Euro / per capita. This situation harms individuals as well as the economy as a whole, because if Albanians provided more they would be able to cope with disasters by insurance companies and would not affect their savings that could be invested, helping so the economic growth. On the other hand, the insurance by saving money or retiring, individuals can be used when someone retires for significant investments.

\section{Chapter 2: Factors influencing demand for life insurance in Albania}

Hypothesis: The demand for life insurance is influenced by economic growth and is influenced by factors such as inflation, education, government policy, population growth, fertility rate, etc.

Based on theoretical studies and a database as Fig. 2.1 shows, we tried to give the factors that influence the demand for life insurance in Albania.

Table 2.1 Factors Influencing the demand for life insurance in Albania

\begin{tabular}{|c|c|c|c|c|c|c|c|c|c|}
\hline Years & $\begin{array}{l}\text { Economic } \\
\text { growt }\end{array}$ & Birth rate & $\begin{array}{l}\text { Gni } \\
\text { per } \\
\text { capita }\end{array}$ & $\begin{array}{l}\text { Inflation } \\
\text { rate }\end{array}$ & $\begin{array}{l}\text { Population } \\
\text { growth (in } \\
\% \text { ) }\end{array}$ & $\begin{array}{l}\text { spending } \\
\text { on } \\
\text { education }\end{array}$ & $\begin{array}{l}\text { (Total } \\
\text { insurance } \\
\text { Premium)/ } \\
\text { GDP }\end{array}$ & $\begin{array}{l}\text { Total Life } \\
\text { insurance } \\
\text { Premium)/ } \\
\text { GDP }\end{array}$ & $\begin{array}{l}\text { Total Non } \\
\text { Life } \\
\text { insuriance } \\
\text { Premium)/ } \\
\text { GDP }\end{array}$ \\
\hline 1999 & 26.17 & 17.8 & 3950 & 0.5 & -0.21 & 16105000 & 0.0038 & 0.0001 & 0.0037 \\
\hline 2000 & 7.37 & 16.92 & 4820 & 1 & -0.03 & 16421000 & 0.0038 & 0.0001 & 0.0037 \\
\hline 2001 & 10.77 & 16.1 & 4980 & 3.5 & 0.18 & 17305000 & 0.005 & 0.0003 & 0.0047 \\
\hline 2002 & 8.32 & 15.35 & 5350 & 6 & 0.4 & 17905000 & 0.0061 & 0.0005 & 0.0056 \\
\hline 2003 & 26.34 & 14.68 & 5770 & 2.4 & 0.55 & 22415407 & 0.0054 & 0.0001 & 0.0053 \\
\hline 2004 & 31.29 & 14.1 & 6220 & 3.2 & 0.58 & 25272916 & 0.0055 & 0.0002 & 0.0053 \\
\hline 2005 & 11.61 & 13.63 & 6980 & 2.4 & 0.54 & 25429735 & 0.0049 & 0.0003 & 0.0046 \\
\hline
\end{tabular}




\begin{tabular}{|l|l|l|l|l|l|l|l|l|l|}
2006 & 8.51 & 13.28 & 7380 & 2.5 & 0.47 & 26228000 & 0.0051 & 0.0003 & 0.0048 \\
\hline 2007 & 16.73 & 13.04 & 8280 & 2.9 & 0.41 & 31305950 & 0.0062 & 0.0004 & 0.0058 \\
\hline 2008 & 20.70 & 12.89 & 8500 & 3.4 & 0.37 & 36022454 & 0.0065 & 0.0005 & 0.0063 \\
\hline 2009 & -6.89 & 12.8 & 8560 & 2.2 & 0.36 & 38606930 & 0.0069 & 0.0006 & 0.0063 \\
\hline 2010 & -2.50 & 11.76 & 7700 & 3.6 & 0.36 & 37469970 & 0.0065 & 0.0007 & 0.0058 \\
\hline 2011 & 1.2 & 11.8 & 7800 & 1.7 & -0.28 & $\begin{array}{l}40,394,45 \\
7\end{array}$ & 0.0064 & 0.0005 & 0.0059 \\
\hline 2012 & 3.3 & 11.22 & 8060 & 2.4 & -0.15 & $\begin{array}{l}38,905,13 \\
6\end{array}$ & 0.0066 & 0.00066 & 0.00594 \\
\hline 2013 & 1.7 & 12.3 & 8200 & 1.9 & -0.11 & $\begin{array}{l}38,899,00 \\
0\end{array}$ & 0.0063 & 0.00072 & 0.00558 \\
\hline
\end{tabular}

Source: AFSA, INSTAT, WB

From the analyses, we have excluded life insurance premium, which from theoretical studies played an important role. This is because the premium, because of the new age insurance in Albania, didn't have fluctuations in time.

Referring to a study done in 2011 , which was based on the same indicators but containing data up to the year 2009, we see that there is a change in the relationship between the demand for life insurance and economic growth. The following table gives the results of statistical processing of data for both periods:

Table 2.2

\begin{tabular}{|l|l|l|l|l|l|l|}
\hline Model & $\begin{array}{l}\text { The dependent } \\
\text { variable }\end{array}$ & $\begin{array}{l}\text { Independent } \\
\text { variable }\end{array}$ & $\begin{array}{l}\text { Regression } \\
\text { coefficient }\end{array}$ & Coefficient R2 & Statistics F & $\begin{array}{l}\text { Level of } \\
\text { significance }\end{array}$ \\
\hline I-2014 & Life insurance & $\begin{array}{l}\text { Economical } \\
\text { growth }\end{array}$ & -11.345 & 241 & 4.169 & 0.000 \\
\hline I-2009 & Life insurance & $\begin{array}{l}\text { Economical } \\
\text { growth }\end{array}$ & 0,000171 & 2 & 0.03 & 0.000 \\
\hline
\end{tabular}

1.Life insurance=425-11.345 Economic growth (2014)

2.Life insurance $=0,202+0,171$ The growth (2009)

Economic growth negatively affects the tendency of Albanian citizens on the request of products of the life insurance industry. The increase in income increases life care and quality, additionally increasing opportunities to cope with and cure sickness or accidents.

Economic growth is not at such levels that significantly increases the personal income of Albanians. Albania remains one of the countries with the lowest income per capita in Europe. Life insurance is considered by Albanians as the best luxury , therefore the model built is consistent with our theoretical approaches.

Model 2

Life insurance=2610-9.29 Economic growth-454.724 Population growth-144 Birth rate

$\mathrm{R}^{2}=0.803$

Stand. Dev. 3.10822133

Stand Dev $-2.989-2.055-4.412$

The model results important. $\mathrm{F}=14.569$ with very important individual links, $\mathrm{t} 1>\mathbf{2}$, with an explanation of $80.3 \%$. There is an absence of autocorrelation ( $d=1.957=2$ ), a not worrying multicollinearity $\mathrm{VIFi}<5$, a normal waste.

PGR- the population growth rate. According to Hammer a growing population resulted in a large number of young people who tend to consume more than they have. As a result, the total savings would be reduced and the demand for financial services too, the same thing happens to life insurance which is part of total savings. The birth rate and health care has 
increased costs for raising children. As a result life insurance would impact positively on reducing the costs savings because if parents have insurance, in case of illnesses they will be reimbursed by insurance companies. The level of spending on education was not a significant factor in our analysis, due to the fact that education on security in schools is lacking. As a summary the two models present a simple regression and a multiple regression.

Table 2.3

\begin{tabular}{|c|c|c|c|c|c|c|}
\hline Model & $\begin{array}{l}\text { The } \\
\text { dependent } \\
\text { variable }\end{array}$ & $\begin{array}{l}\text { The independent } \\
\text { variable }\end{array}$ & $\begin{array}{l}\text { Regression } \\
\text { coefficient }\end{array}$ & Coefficient $R^{2}$ & Statistics F & $\begin{array}{l}\text { Level of } \\
\text { significance }\end{array}$ \\
\hline $\mathrm{I}$ & $\begin{array}{l}\text { Life } \\
\text { insurance }\end{array}$ & Economic growth & $-11.345^{*}$ & 0.241 & 4.169 & 0.000 \\
\hline \multirow{3}{*}{ II } & \multirow{3}{*}{$\begin{array}{l}\text { Life } \\
\text { insurance }\end{array}$} & Economic growth & $-9.29^{*}$ & \multirow{3}{*}{0.803} & \multirow{3}{*}{14.569} & \multirow{3}{*}{0.000} \\
\hline & & Population & $-454.724^{*}$ & & & \\
\hline & & Birth rate & $-4.412^{*}$ & & & \\
\hline
\end{tabular}

Below we will discuss another set of factors which, even if we did not include them in the study, they have an impact on the demand for life insurance:

- The religious population trend could affect the risk rejection and their attitude towards the institutional arrangements of insurance. But although supporters of Islam have traditionally opposed life insurance, in Albania this phenomenon does not affect the demand for insurance.

We expect the development of the banking sector in Albania to be positively associated with the consumption of life insurance. Banks that work well can enhance customer confidence in other financial institutions, such as life insurance companies.

- They also provide for life insurers an efficient payment system. Although we were unable to measure this phenomenon we think it has an impact, even if it is a small impact.

- The size of the social security system in our country theoretically tends to be negatively associated with the demand for insurance products. We will refer to the minimum payment of pensions, incapacity for work or the life fact that the reimbursement by health insurance is almost dysfunctional in Albanian.

The polarization of society - is another negative factor. Rich layers of society usually do not have insurance because they do not need it while other classes can't afford insurance.

\section{Conclusions and recommendations}

The market of life insurance owns no more than $10-11 \%$ of the insurance market in Albania.

-Albanians are part of a community less secured in Europe, a fact that leaves room for thinking that there are large unused capacities in the life insurance industry.

- The economic importance of the insurance sector and in particular of the life insurance sector is still low as measured by the amount of investments made by this sector, the insurance density and the penetration coefficient.

- Foreign capital owns about $42 \%$ of the life insurance market.

- The main reason for a low level in life insurance sector is related to the lack of a tradition in insurance and a lack of culture that people have to be insured, the lack of a national awareness campaign about the financial system and the insurance system in particular.

-In Albania, life insurance is still treated as a luxury. An increase in GDP or income per capita does not cause increased demand for life insurance.

- Demographic factors adversely affect the demand for life insurance, this is noted during the statistical analysis. 
- In more than 20 years of life insurance development in Albania, few people or barely one has stopped to think that these markets should be part of the overall social, educational, economic, legal and public discussion. This approach has produced, of course, a negative effect.

- The life insurance industry in Albania suffers from a major handicap, the lack of a qualified personnel. This can have a significant impact on the lack of supply with insurance services.

\section{Recommendations}

- Development of life insurance should be treated as a public good, as this is his mission.

- All factors, public and private actors in the field of life insurance, the civil society, educational and academic institutions, they all must commit themselves to analyze, select and design development programs of the insurance industry, which due to its nature has an indisputable impact on the national socio-economic development.

- The impact of the government's incentive policies and support for the insurance industry would increase the role of this sector in economic development.

- Education with literature in the field of insurance, starting from 9-year-old school students and beyond would increase the demand for life insurance in the future .

\section{References}

[1] AFSA Anual Reports

[2] Arrow, K. J. (1965). 'Insurance, Risk and Resource Allocation' in "Foundations of InsuranceEconomics",

[3] G. Dionne and S. E. Harrington (eds.), Kluwer Academic Publishers.

[4] Beenstock, M., Dickinson, G. and Khajuria, S. (1986), The Determination of Life Premiums: an

[5] International Cross-Section Analysis 1970-1981, Insurance: Mathematics and Economics 5, 261 -

[6] 70.

[7] Beck, T. and I. Webb (2003) "Economic, Demographic, and Institutional Determinants of Life Insurance Consumption Across Countries", World Bank Economic Review, Vol. 17; pp 51-88.

[8] Browne, Mark J. and Kim, Kihong (1993): An International Analysis of Life Insurance Demand, Journal

[9] of Risk and Insurance 60, 616-634.

[10] Campbell, R. A. (1980), The Demand for Life Insurance: An Application of the Economics of

[11] Uncertainty, Journal of Finance 35, 1155-1172

[12] Cargill, T. F. and T. E. Troxel (1979) "Modelling Life Insurance Savings: Some Methodological

[13] Issues", Journal of Risk and Insurance, Vol. 46; pp 391-410.

[14] Fisher, S. (1973) "A Life Cycle Model of Life Insurance Purchases", International Economic Review, Vol. 14; pp $132-52$.

[15] Lewis, Frank, D. (1989): Dependents and the Demand for Life Insurance, American Economic Review

[16] 79, $452-466$.

[17] Madani, F. Muharremi,O. Ramaj,B. Pelari, E.(2014) "The Life Insurance - how acceptable are for the Albanians and the factors affecting their level" Academic Journal of Interdisciplinary Studies MCSER Publishing, RomeItaly, Vol. 3, No 3, pp $243-251$.

[18] Outreville, J. F. (1996) "Life Insurance Markets in Developing Countries", Journal of Risk and Insurance, Vol. 63; pp 263-278.

[19] Truett, D. B. and L. J. Truett (1990) "The Demand for Life Insurance in Mexico and the United States: A Comparative Study", Journal of Risk and Insurance, Vol. 57; pp 321-328.

[20] Swiss Reinsurance Company, World Insurance, Various years, Sigma. Zurich: Swiss Reinsurance

[21] Company.

[22] Yaari, Menahem E. (1965): Uncertain Lifetime, Life Insurance, and the Theory of the Consumer, Review

[23] of Economic Studies 32, 137-150.

[24] Zelizer, Vivian R. (1979): Morals and Markets: The Development of Life Insurance in the United States,

[25] Columbia University Press, New York, NY. 


\section{Apendix}

Variables Entered/Removed

\begin{tabular}{|l|l|l|l|}
\hline Model & Variables Entered & Variables Removed & Method \\
\hline 1 & ECO_GROWTH & & Enter \\
\hline
\end{tabular}

a. Dependent Variable: LIFE_INS

b. All requested variables entered.

Model Summaryb

\begin{tabular}{|l|l|l|l|l|l|}
\hline Model & R & Adjusted R Square & $\begin{array}{l}\text { Std. Error of the } \\
\text { Estimate }\end{array}$ & Durbin-Watson \\
\hline 1 & $.563^{a}$ & .317 & .241 & 192.937 & 1.949 \\
\hline
\end{tabular}

a. Predictors: (Constant), ECO_GROWTH

b. Dependent Variable: LIFE_INS

ANOVAa $^{a}$

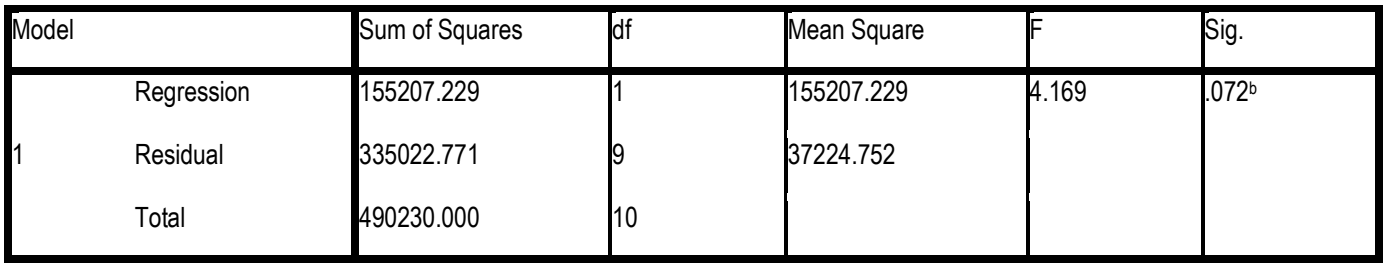

a. Dependent Variable: LIFE_INS

b. Predictors: (Constant), ECO_GROWTH

Coefficients ${ }^{a}$

\begin{tabular}{|c|c|c|c|c|c|c|c|}
\hline \multirow[t]{2}{*}{ Model } & \multicolumn{2}{|c|}{ Unstandardized Coefficients } & \multirow{2}{*}{\begin{tabular}{|l|}
$\begin{array}{l}\text { Standardized } \\
\text { Coefficients }\end{array}$ \\
Beta
\end{tabular}} & \multirow[t]{2}{*}{$t$} & \multirow[t]{2}{*}{ Sig. } & \multicolumn{2}{|c|}{ Collinearity Statistics } \\
\hline & $B$ & Std. Error & & & & Tolerance & VIF \\
\hline $\begin{array}{l}\text { (Constant) } \\
\text { ECO_GROWTH }\end{array}$ & $\begin{array}{l}425.986 \\
-11.345\end{array}$ & $\begin{array}{l}99.960 \\
5.556\end{array}$ & -.563 & $\begin{array}{l}4.262 \\
-2.042\end{array}$ & $\begin{array}{l}.002 \\
.072\end{array}$ & 1.000 & 1.000 \\
\hline
\end{tabular}

a. Dependent Variable: LIFE_INS

Collinearity Diagnosticsa

\begin{tabular}{|ll|l|l|l|l|}
\hline Model & Dimension & Eigenvalue & Condition Index & \multicolumn{2}{|l|}{ Variance Proportions } \\
\cline { 4 - 6 } & & & & (Constant) & ECO_GROWTH \\
\hline 1 & 1.813 & 1.000 & .09 & .09 \\
2 & 187 & 3.116 & .91 & .91 \\
\hline
\end{tabular}


a. Dependent Variable: LIFE_INS

Residuals Statisticsa

\begin{tabular}{|l|l|l|l|l|l|}
\hline & Minimum & Maximum & Mean & Std. Deviation & N \\
\hline Predicted Value & 70.99 & 504.11 & 260.00 & 124.582 & 11 \\
Residual & -333.321 & 323.878 & .000 & 183.036 & 11 \\
Std. Predicted Value & -1.517 & 1.959 & .000 & 1.000 & 11 \\
Std. Residual & -1.728 & 1.679 & .000 & .949 & 11 \\
\hline
\end{tabular}

a. Dependent Variable: LIFE_INS

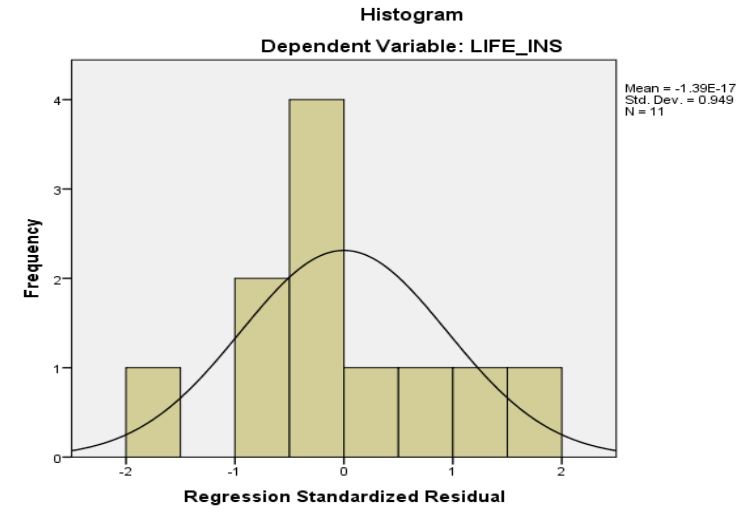

\section{Residual Plots for CP_Life Insurance}

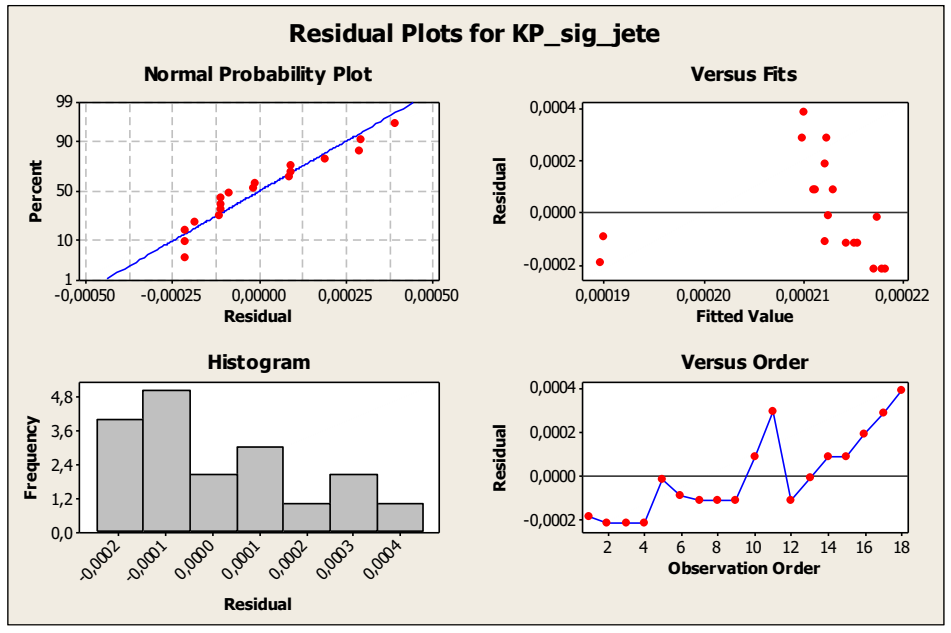

